\title{
Serum Neutrophil Gelatinase- Associated Lipocalin as a Marker of Malnutrition in Maintenance Hemodialyzed Patients
}

\author{
Anas Abd AlRahman, Hesham A. Esaa, Enas S. Ahmad, Seham S. Mohammed
}

\begin{abstract}
Department of clinical and chemical pathology, Faculty of Medicine, Benha University, Egypt.
\end{abstract}

Correspondence to: Seham S. Mohammed, department of clinical and chemical pathology, Faculty of Medicine, Benha university, Egypt.

Email:

sehamsobhy222@gmail.com

Received: 30 September 2019

Accepted: 9 February 2021

\begin{abstract}
:
Background: Neutrophil Gelatinase- Associated Lipocalin (NGAL) is a useful clinical biomarker for early diagnosis, predicting disease severity, therapeutic monitoring, and for predicting clinical outcomes. Aim: The current study aimed to investigate serum Neutrophil gelatinase-associated lipocalin ( NGAL ) levels as a marker of malnutrition in maintenance hemodialysis patients. Subjects and methods: This study was conducted on 50 subjects. Subjects were divided into three groups .Group (1): Hemodialyzed patients : Included 30 patients before starting hemodialysis (HD). Group (2): The same 30 patients after hemodialysis. Group (3): Included control group. Serum levels of NGAL was measured by enzyme-linked immunosorbent assay (ELISA ). Results: There is high statistically significant decrease in NGAL in dialyzed patients after dialysis when compared to the same patients before dialysis $(\mathrm{p}<0.001)$. There is statistically significant positive correlation
\end{abstract} between NGAL after dialysis and albumin, pre-albumin, serum iron, serum ferritin, TLC and neutrophils \%. There is a statistically significant decrease in the serum level of NGAL (before and after) in dialysis patients with malnutrition when compared to ( before and after ) dialysis patients without malnutrition. Conclusion: Serum level of NGAL seems to be a reliable marker of malnutrition appearance, allowing early diagnosis and preventive therapy.

Key words: Neutrophil Gelatinase Associated Lipocalin (NGAL), malnutrition, hemodialysis. 



\section{Introduction}

Dialysis is a treatment for severe kidney failure (also called renal failure or end-stage renal disease). When the kidneys are no longer working effectively, waste products and fluid buildup in the blood (1). Proteinenergy malnutrition is present in a large proportion of maintenance hemodialysis (HD) patients, and it is associated with increased morbidity and mortality.

The protein requirements are increased because of the presence of endocrine and metabolic factors related to loss of renal function, the HD procedure, and comorbidity factors, which all stimulate protein catabolism (2). Neutrophil Gelatinase Associated Lipocalin (NGAL) is a protein produced in the distal tubule of the nephron. NGAL's function is to aid in the conversion of metanephric mesenchyme into epithelia during the formation of the kidney (3).

NGAL is a $25 \mathrm{kDa}$ glycoprotein of the lipocalin family, which consists of a single disulfide bridged polypeptide chain of 178 amino acid residues that is stored in granules of neutrophil leukocytes (4). Although the major source of plasma NGAL are neutrophils it is also found in monocytes, hepatocytes, endothelial and smooth muscle cells, renal tubular cells . It has been linked to acute tubular kidney injury, chronic kidney disease progression, neutrophil activation and atherogenesis (1). NGAL is increased in the setting of both acute and chronic kidney damage and is excreted into the urine where it can be measured. In addition the level of NGAL expressed in the various forms of kidney damage varies (5).

The aim of the present study was to investigate serum neutrophil gelatinaseassociated lipocalin (NGAL) levels as a marker of malnutrition in maintenance hemodialysis patients.

\section{Subjects and methods}

The present study was a case control study. It was conducted on fifty subjects. The samples were collected from May 2017 to May 2018. They were chosen from patients attending hemodialysis unit in Benha university hospital and Benha teaching hospital with written consent. An approval had been obtained from ethical committee of Benha University and from patients included in the study. Inclusion criteria: Patients more than eighteen years old and hemodialyzed patients. Exclusion criteria: Patients less than eighteen years old, patient refused to contribute in the study and 
patients with acute kidney disease. The cases were divided into the following groups: Group (1): included twenty age and sex matched apparently healthy subjects recruited as a control group, they were 8 males (40\%) and 12 females (60\%), with their age ranged from 33-59years (mean $50.9 \pm 6.9$ years). Group (2): hemodialyzed patients before hemodialysis: included thirty patients suffering from chronic renal failure before starting hemodialysis (HD) treatment. They were eleven females $(36.7 \%)$ and nineteen males (63.3\%), with their age

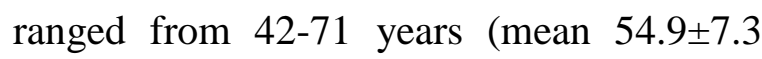
years).

They were chosen from patients attending hemodialysis Unit in Benha University Hospital and Benha Teaching Hospital. Group (3): patients after period of hemodialysis (4-6 months): included the same thirty hemodialyzed patients. All subjects had been subjected to: A) Clinical evaluation including: 1) Complete history taking, 2) General examination: including pulse and blood pressure measurement and 3) Local examination : for the abdomen and pelvis . B) Laboratory investigation: Serum Neutrophil gelatinaseassociated lipocalin (NGAL) levels were determined by enzyme-linked immunosorbent assay (Shanghai Sunred
Biological Technology Company in Shanghai, China), Serum albumin: was estimated by Modified bromocresol green colorimetric method (6), prealbumin level was determined by enzyme-linked immunosorbent assay (Shanghai Sunred Biological Technology Company in Shanghai, China) Catalog No. 201-121183, Iron status: TIBC (total iron binding capacity) performed by the colorimetric method used for iron determination (7), serum iron was measured calorimetrically (8) by BioSystem BTS - 310 (Biosystem company, Spain) and serum ferritin was measured by a solid phase enzyme-linked immunosorbent assay (Immunospec Corporation Company in Canoga Park, California, United States) Catalog No. E29-013, C-reactive protein (CRP): was estimated by AVITEX CRP latex agglutination (9), Random blood sugar (RBS): was estimated in serum by Glucose Oxidase (GOD) method (10), Serum creatinine level: was estimated by Jaffe method (11). All chemical measurements were done using Bio Systems BTS - 310 (Bio system company, Spain) and CBC ( Complete blood count) including neutrophil count: $\mathrm{CBC}$ was estimated by $\mathrm{ABX}$ MICRO 60 OS/OT( 34184 Montpellier Cedex 04 -France). 
All the laboratory investigations had been done before and after 4-6 months dialysis.

\section{Sampling:}

Six milliliters of peripheral venous blood were taken from each subject under complete aseptic conditions. The sample was divided into two tubes one containing EDTA for hematological investigations and the other plain tube was left for spontaneous clotting then centrifuged at $3000 \mathrm{rpm}$ for 10 minutes for serum separation. Serum was used for measurement of biochemical investigations and the rest of sample was stored at $\left(-20^{\circ} \mathrm{C}\right)$ till the time of assay of NGAL. Serum NGAL measurement was done by enzyme linked immunosorbent assay (ELISA). Blood samples were collected before starting hemodialysis treatment and after a period of hemodialysis (four to six months). To examine serial changes in blood concentrations of NGAL and other parameters.

\section{$\underline{\text { Statistical analysis }}$}

The collected data were tabulated and analyzed using SPSS version 16 soft ware (SPSS Inc, Chicago, ILL Company USA). Categorical data were presented as number and percentages while quantitative data were expressed as mean \pm standard deviation, median and range. Chi square test $\left(\mathrm{X}^{2}\right)$, or
Fisher's exact test (FET) were used to analyze categorical variables. Quantitative data were tested for normality using Shapiro-Wilks test, assuming normality at $\mathrm{P}>0.05$, using Student " $\mathrm{t}$ ", Paired " $\mathrm{t}$ " test, if normally distributed, or Wilcoxon test, Man Whitney U test and Spearman's correlation coefficient ( rho ) if not normally distributed. ROC curve was used to determine cutoff value of NGAL with optimum sensitivity and specificity in prediction of malnutrition. The accepted level of significance in this work was stated at 0.05 ( $\mathrm{P}<0.05$ was considered significant). Binary logistic regression was used to detect the significant predictors of malnutrition.

\section{Results}

In this study, regarding the age, the mean age of the patients groups was $54.9 \pm 7.3$ years; with a range of 42-71 years while in control group was $50.9 \pm 6.9$ years with a range of 33-59 years. The difference between the two groups was not significant. Regarding the sex, patients groups included $36.7 \%$ females and $63.3 \%$ males. Control group included (60\%) females and (40\%) males.

There is high statistically significant decrease in NGAL in dialyzed patients after 
dialysis when compared to the same patients before dialysis. There is statistically significant increase in NGAL in dialyzed patients before dialysis when compared to control group as shown in table (1). There is high statistically significant decrease in albumin and pre-albumin in dialyzed patients after dialysis when compared to the same patients before dialysis.

There is high statistically significant decrease in albumin in dialyzed patients (before and after) dialysis when compared to control group. There is high statistically significant decrease in pre-albumin in dialyzed patients after dialysis when compared to control group as shown in table (2). There is high statistically significant decrease in serum iron and serum ferritin in dialyzed patients after dialysis when compared to the same patients before dialysis.

There is high statistically significant decrease in serum iron in dialyzed patients ( before and after ) dialysis when compared to control group.

There is statistically significant decrease in serum ferritin in dialyzed patients after dialysis when compared to control group. There is high statistically significant increase in TIBC in dialyzed patients after dialysis when compared to the same patients before dialysis. There is high statistically significant increase in TIBC in dialyzed patients (before and after) dialysis when compared to control group as shown in table (3). There is high statistically significant decrease in $\mathrm{Hb} \%$ in dialyzed patients after dialysis when compared to the same patients before dialysis.

There is high statistically significant decrease in $\mathrm{Hb} \%$ in dialyzed patients (before and after) dialysis when compared to control group. There is high statistically significant increase in TLC and neutrophils \% in dialyzed patients (before and after) dialysis when compared to control group. There is statistically significant positive correlation between NGAL before dialysis and serum creatinine, TLC and Neutrophils $\%$ as shown in table (4).

There is statistically significant positive correlation between NGAL after dialysis and albumin, pre-albumin, serum iron, serum ferritin, TLC and neutrophils \%. There is statistically significant negative correlation between NGAL after dialysis and TIBC as shown in table (8). There is a statistically significant decrease in NGAL (before and after) dialysis patients with 
malnutrition when compared to (before and

after) dialysis patients without malnutrition.

Table (1): NGAL level (ng/ml) among the studied groups .

Variable

Patients $(\mathbf{N}=30)$

\begin{tabular}{|c|c|c|c|c|c|c|c|c|c|c|c|c|}
\hline & \multicolumn{3}{|c|}{$\begin{array}{l}\text { Before starting treatment } \\
\text { with dialysis (Befor dialysis }\end{array}$} & \multicolumn{3}{|c|}{$\begin{array}{l}\text { After aperiod of dialysis } \\
\text { (After dialysis) }\end{array}$} & \multicolumn{3}{|c|}{ Controls $\quad(\mathbf{N}=\mathbf{2 0})$} & \multirow[t]{2}{*}{$\begin{array}{l}\text { Wilcoxon } \\
\text { test \& P }\end{array}$} & \multirow[t]{2}{*}{$\begin{array}{l}\mathbf{M W U}_{1} \\
\text { test } \\
\& \mathbf{P}_{1}\end{array}$} & \multirow[t]{2}{*}{$\begin{array}{l}\mathbf{M W U}_{2} \\
\text { test } \\
\& \mathbf{P}_{2}\end{array}$} \\
\hline & Mean & $\pm \mathrm{SD}$ & $\begin{array}{l}\text { Median } \\
\text { (Range) }\end{array}$ & Mean & \pm SD & $\begin{array}{l}\text { Median } \\
\text { (Range) }\end{array}$ & Mean & \pm SD & $\begin{array}{l}\text { Median } \\
\text { (Range) }\end{array}$ & & & \\
\hline \multirow{3}{*}{$\begin{array}{l}\text { NGAL } \\
(\mathrm{ng} / \mathrm{ml})\end{array}$} & \multirow{3}{*}{977.0} & \multirow{3}{*}{475.03} & 785.5 & \multirow{3}{*}{653.1} & \multirow{3}{*}{432.10} & \multirow{3}{*}{$\begin{array}{l}585.0 \\
(100- \\
2148)\end{array}$} & \multirow{3}{*}{721.2} & \multirow{3}{*}{192.84} & 663.0 & \multirow{3}{*}{$\begin{array}{l}4.78 \\
\&<0.001 \\
\text { (HS) }\end{array}$} & $2.89 \&$ & $1.41 \&$ \\
\hline & & & (510- & & & & & & $(30-$ & & & \\
\hline & & & 2383) & & & & & & 1001) & & $(\mathrm{S})$ & (NS) \\
\hline
\end{tabular}

Wilcoxon test $\& \mathrm{P} \rightarrow$ between patients before and after dialysis

$\mathrm{MWU}_{1}$ test $\& \mathrm{P}_{1} \rightarrow$ between patients before and controls

Table (2): Albumin (gm/dl) and pre albumin (mg/dl) among the studied groups .

\begin{tabular}{|c|c|c|c|c|c|c|c|c|c|c|c|c|}
\hline \multirow[t]{3}{*}{ Variable } & \multicolumn{5}{|c|}{ Patients $(\mathrm{N}=30)$} & \multirow{2}{*}{\multicolumn{4}{|c|}{ Controls $(\mathrm{N}=\mathbf{2 0})$}} & \multirow{3}{*}{$\begin{array}{l}\text { Paired } \\
\text { "t" } \\
\text { test \& } \\
\text { P }\end{array}$} & \multirow{3}{*}{$\begin{array}{l}\text { St." } t " \\
1 \text { test } \\
\& P_{1}\end{array}$} & \multirow{3}{*}{$\begin{array}{l}\text { St."t" } \\
\text { test } \& P_{2}\end{array}$} \\
\hline & \multicolumn{3}{|c|}{ Before dialysis } & \multicolumn{2}{|c|}{ After dialysis } & & & & & & & \\
\hline & Mean & $\pm \mathrm{SD}$ & Range & Mean & \pm SD & Range & Mean & \pm SD & Range & & & \\
\hline \multirow{3}{*}{$\begin{array}{l}\text { Serum } \\
\text { Albumin } \\
\text { (gm/dl) }\end{array}$} & \multirow{3}{*}{3.88} & \multirow{3}{*}{0.28} & \multirow{3}{*}{$3.4-4.4$} & \multirow{3}{*}{3.37} & \multirow{3}{*}{0.32} & \multirow{3}{*}{$2.9-3.9$} & \multirow{3}{*}{4.35} & \multirow{3}{*}{0.32} & \multirow{3}{*}{$\begin{array}{l}3.8- \\
4.9\end{array}$} & 12.6 & $5.32 \&$ & $10.4 \&$ \\
\hline & & & & & & & & & & $\&<0.0$ & $<0.001$ & \multirow{2}{*}{$\begin{array}{l}<0.001 \\
(\mathrm{HS})\end{array}$} \\
\hline & & & & & & & & & & $\begin{array}{l}01 \\
\text { (HS) }\end{array}$ & (HS) & \\
\hline \multirow{3}{*}{$\begin{array}{l}\text { Serum pre } \\
\text { albumin } \\
(\mathrm{mg} / \mathrm{dl})\end{array}$} & \multirow{3}{*}{32.13} & \multirow{3}{*}{2.45} & \multirow{3}{*}{$28-36$} & \multirow{3}{*}{27.23} & \multirow{3}{*}{2.38} & \multirow{3}{*}{$22-31$} & \multirow{3}{*}{33.40} & \multirow{3}{*}{2.11} & \multirow{3}{*}{$30-37$} & 13.2 & $1.88 \&$ & $9.4 \&$ \\
\hline & & & & & & & & & & $<0.001$ & 0.066 & $<0.001$ \\
\hline & & & & & & & & & & (HS) & (NS) & (HS) \\
\hline
\end{tabular}

Paired "t" test $\& \mathrm{P} \rightarrow$ between patients before and after dialysis

St."t" ${ }_{1}$ test $\& \mathrm{P}_{1} \rightarrow$ between patients before and controls

St. " $\mathrm{t}{ }_{2}$ test $\& \mathrm{P}_{2} \rightarrow$ between patients after dialysis and controls 
Benha medical journal vol.38, issue 1, 2021

Table (3): Serum iron (mg/dl), ferritin (ng /ml) and TIBC (mg/dl) among the studied

\begin{tabular}{|c|c|c|c|c|c|c|c|c|c|c|c|c|}
\hline \multirow{3}{*}{ Variable } & \multicolumn{6}{|c|}{ Patients $(\mathrm{N}=\mathbf{3 0})$} & \multirow{2}{*}{\multicolumn{3}{|c|}{ Controls $(\mathrm{N}=\mathbf{2 0})$}} & \multirow{3}{*}{$\begin{array}{c}\text { Wilcox } \\
\text { on test } \\
\text { \& P }\end{array}$} & \multirow{3}{*}{$\begin{array}{c}\mathrm{MWU}_{1} \\
\text { test } \\
\& \mathbf{P}_{1}\end{array}$} & \multirow{3}{*}{$\begin{array}{r}\mathrm{MWU}_{2} \\
\text { test } \& \mathbf{P}_{2}\end{array}$} \\
\hline & \multicolumn{3}{|c|}{ Before dialysis } & \multicolumn{3}{|c|}{ After dialysis } & & & & & & \\
\hline & Mean & \pm SD & $\begin{array}{l}\text { Median } \\
\text { (Range) }\end{array}$ & Mean & \pm SD & $\begin{array}{l}\text { Median } \\
\text { (Range) }\end{array}$ & Mean & \pm SD & $\begin{array}{l}\text { Median } \\
\text { (Range) }\end{array}$ & & & \\
\hline $\begin{array}{l}\text { Serum } \\
\text { iron } \\
(\mathrm{mg} / \mathrm{dl})\end{array}$ & 57.6 & 13.28 & $\begin{array}{c}53.5 \\
(40-90)\end{array}$ & 40.1 & 9.15 & $\begin{array}{c}38 \\
(28-70)\end{array}$ & 86.7 & $\begin{array}{c}18.2 \\
9\end{array}$ & $\begin{array}{c}89.5 \\
(45-123)\end{array}$ & $\begin{array}{c}4.71 \\
\&<0.00 \\
1(\mathrm{HS})\end{array}$ & $\begin{array}{c}4.81 \\
\&<0.00 \\
1 \text { (HS) }\end{array}$ & $\begin{array}{c}5.82 \\
\&<0.001 \\
(\mathrm{HS})\end{array}$ \\
\hline $\begin{array}{l}\text { Serum } \\
\text { ferritin } \\
(\mathrm{ng} / \mathrm{ml})\end{array}$ & 98.9 & 24.66 & $\begin{array}{l}90.5 \\
(60- \\
192)\end{array}$ & 76.2 & $\begin{array}{c}16.9 \\
1\end{array}$ & $\begin{array}{c}72.5 \\
(49-125)\end{array}$ & 121.9 & $\begin{array}{c}73.9 \\
6\end{array}$ & $\begin{array}{c}89.5 \\
(31-299)\end{array}$ & $\begin{array}{c}4.7 \\
\&<0.00 \\
1(\mathrm{HS})\end{array}$ & $\begin{array}{c}0.69 \\
\& 0.49 \\
(\mathrm{NS})\end{array}$ & $\begin{array}{c}2.79 \\
\& 0.005 \\
(\mathrm{~S})\end{array}$ \\
\hline $\begin{array}{l}\text { TIBC } \\
(\mathrm{mg} / \mathrm{dl})\end{array}$ & 250.4 & 26.23 & $\begin{array}{l}252.5 \\
(200- \\
300)\end{array}$ & 277.5 & 27.0 & $\begin{array}{l}277 \\
(210- \\
321)\end{array}$ & 214.7 & 24.7 & $\begin{array}{c}210 \\
(171-260)\end{array}$ & $\begin{array}{c}3.28 \& \\
0.001 \\
(\mathrm{HS})\end{array}$ & $\begin{array}{c}4.03 \\
\&<0.00 \\
1(\mathrm{HS})\end{array}$ & $\begin{array}{c}5.42 \& \\
<0.001 \\
(\mathrm{HS})\end{array}$ \\
\hline
\end{tabular}

Wilcoxon test $\& \mathrm{P} \rightarrow$ between patients before and after dialysis

$\mathrm{MWU}_{1}$ test \& $\mathrm{P}_{1} \rightarrow$ between patients before and controls

$\mathrm{MWU}_{2}$ test $\& \mathrm{P}_{2} \rightarrow$ between patients after dialysis and controls

Table (4): CBC parameters among the studied groups.

\begin{tabular}{|c|c|c|c|c|c|c|c|c|c|c|c|c|}
\hline \multirow{3}{*}{ Variable } & \multicolumn{6}{|c|}{ Patients $(\mathrm{N}=30)$} & \multirow{2}{*}{\multicolumn{3}{|c|}{ Controls $(\mathrm{N}=\mathbf{2 0})$}} & \multirow{3}{*}{$\begin{array}{l}\text { Wilcox } \\
\text { on test } \\
\& P\end{array}$} & \multirow{3}{*}{$\begin{array}{l}\mathbf{M W U}_{1} \\
\text { test } \\
\& \mathbf{P}_{1}\end{array}$} & \multirow{3}{*}{$\begin{array}{l}\mathbf{M W U}_{2} \\
\text { test } \\
\& \mathbf{P}_{2}\end{array}$} \\
\hline & \multicolumn{2}{|c|}{ Before dialysis } & \multicolumn{4}{|c|}{ After dialysis } & & & & & & \\
\hline & Mean & $\pm \mathrm{SD}$ & $\begin{array}{l}\text { Median } \\
\text { (Range) }\end{array}$ & Mean & $\begin{array}{l} \pm \mathbf{S} \\
\mathrm{D}\end{array}$ & $\begin{array}{l}\text { Median } \\
\text { (Range) }\end{array}$ & Mean & $\pm \mathrm{SD}$ & $\begin{array}{l}\text { Median } \\
\text { (Range) }\end{array}$ & & & \\
\hline & & & 11.1 & & & 9.75 & & & 13.0 & 4.77 & 4.72 & 5.96 \\
\hline $\mathbf{H b} \%$ & 11.2 & 0.92 & $(9.5-13)$ & 9.6 & 0.91 & $(8-11.2)$ & 12.8 & 0.85 & $\begin{array}{l}(11.8- \\
14.5)\end{array}$ & $\begin{array}{l}\&<0.001 \\
(\mathrm{HS})\end{array}$ & $\begin{array}{l}\&<0.001 \\
(\mathrm{HS})\end{array}$ & $\begin{array}{l}\&<0.001 \\
(\mathrm{HS})\end{array}$ \\
\hline & & & 5550 & & & 6500 & & & 4400 & 1.8 & $4.33 \&$ & 5.12 \\
\hline TLC & 6556.6 & $\begin{array}{l}2220 . \\
07\end{array}$ & $\begin{array}{l}(4700- \\
13000)\end{array}$ & 7843.3 & $\begin{array}{l}3060 \\
.05\end{array}$ & $\begin{array}{l}(4700- \\
15000)\end{array}$ & $\begin{array}{l}4495 . \\
0\end{array}$ & 493.61 & $\begin{array}{l}(3800- \\
5200)\end{array}$ & $\begin{array}{l}0.072 \\
(\mathrm{NS})\end{array}$ & $\begin{array}{l}<0.001 \\
(\mathrm{HS})\end{array}$ & $\begin{array}{l}\& \\
<0.001 \\
(\mathrm{HS})\end{array}$ \\
\hline $\begin{array}{l}\text { Neutrophils } \\
\%\end{array}$ & 53.4 & 5.45 & $\begin{array}{l}51.5 \\
(45-67)\end{array}$ & 56.4 & 6.27 & $\begin{array}{l}55.0 \\
(48-69)\end{array}$ & 48.6 & 2.41 & $\begin{array}{l}48.5 \\
(44-52)\end{array}$ & $\begin{array}{l}1.89 \\
\& 0.058 \\
(\mathrm{NS})\end{array}$ & $\begin{array}{l}\& 0.001 \\
(\mathrm{HS})\end{array}$ & $\begin{array}{l}4.59 \& \\
<0.001 \\
(\mathrm{HS})\end{array}$ \\
\hline
\end{tabular}


Table (5): Prevalence of malnutrition among patients after HD.

\begin{tabular}{ccc}
\hline Malnutrition & Frequency & Percent \\
\hline No & 5 & 16.7 \\
Yes & 25 & 83.3 \\
Total & 30 & 100.0 \\
\hline
\end{tabular}

Table (6) : Binary logistic regression analysis for predictors of malnutrition.

\begin{tabular}{|c|c|c|c|c|}
\hline Variable & B & OR & $95 \% \mathrm{CI}$ & $\mathbf{P}$ \\
\hline $\begin{array}{l}\text { NGAL before HD } \\
\leq 849(\mathrm{ng} / \mathrm{ml})\end{array}$ & 3.94 & 15.5 & $3.1-29.7$ & $0.016(\mathrm{~S})$ \\
\hline $\begin{array}{l}\text { NGAL after HD } \\
\leq 600.5(\mathrm{ng} / \mathrm{ml})\end{array}$ & 4.48 & 23.9 & 7.3-33.5 & $0.003(\mathrm{~S})$ \\
\hline $\begin{array}{l}\text { Albumin after dialysis } \\
\leq 3.85(\mathrm{~g} / \mathrm{dl})\end{array}$ & 2.63 & 5.87 & $1.21-9.9$ & $0.029(\mathrm{~S})$ \\
\hline
\end{tabular}

Table (7): Correlation between NGAL and the studied variables among patients group before dialysis.

\begin{tabular}{lll}
\hline With & \multicolumn{2}{c}{ NGAL } \\
& \multicolumn{2}{c}{ Patients pre dialysis (N=30) } \\
& rho & P \\
\hline Age (years) & 0.009 & 0.96 \\
Period of HD(y) & -0.292 & 0.11 \\
Albumin(gm/dl) & 0.1 & 0.59 \\
Pre albumin(mg/dl) & -0.281 & 0.13 \\
S iron(mg/dl) & -0.223 & 0.23 \\
s. ferritin(ng/dl) & 0.002 & 0.99 \\
TIBC(mg/dl) & -0.091 & 0.63 \\
RBS(mg/dl) & -0.018 & 0.92 \\
S creat(mg/dl) & 0.723 & $<0.001$ (HS) \\
Hb\% & -0.065 & 0.73 \\
TLC & 0.498 & 0.005 (S) \\
Neutrophils \% & 0.424 & 0.02 (S) \\
\hline
\end{tabular}


Table (8): Correlation between NGAL and the studied variables among patients group after dialysis.

\begin{tabular}{lcc}
\hline With & \multicolumn{2}{c}{ NGAL } \\
& \multicolumn{2}{c}{ Patients post dialysis $(\mathbf{N}=\mathbf{3 0})$} \\
& rho & P \\
\hline Age (years) & -0.117 & 0.53 \\
Period of HD(y) & 0.211 & 0.26 \\
Albumin(gm/dl) & 0.681 & $0.001(\mathrm{HS})$ \\
Pre albumin(mg/dl) & 0.594 & $0.006(\mathrm{~S})$ \\
S iron(mg/d) & 0.570 & $0.001(\mathrm{HS})$ \\
S. ferritin(ng/dl) & 0.396 & $0.03(\mathrm{~S})$ \\
TIBC(mg/dl) & -0.469 & $0.009(\mathrm{~S})$ \\
RBS(mg/dl) & -0.146 & 0.44 \\
S creat(mg/dl) & 0.095 & 0.61 \\
Hb\% & 0.062 & 0.74 \\
TLC & 0.539 & $0.008(\mathrm{~S})$ \\
Neutrophils \% & 0.643 & $0.001(\mathrm{HS})$ \\
\hline
\end{tabular}

\section{Discussion}

Kidney function can be lost rapidly (acute renal failure or acute kidney injury) or over months or years (chronic kidney disease). Early in the course of kidney disease, other treatments are used to help preserve kidney function and delay the need for replacement therapy (12). Patients receiving maintenance HD are a unique group of subjects whose clinical parameters are closely monitored in routine practice. Furthermore, their dietary protein intake and muscle mass can be estimated by formulas using blood urea nitrogen (BUN) and creatinine levels before and after HD session (13). NGAL, identified as component of neutrophil granules, inhibits bacterial growth by depleting their intracellular iron stores (14). NGAL is an acute-phase protein induced in inflammatory conditions and ischemia, and a reliable biomarker for predicting acute kidney injury (AKI) in various clinical setting (15). In the present study there were statistically significant differences between the groups as regard NGAL as there is high statistically 
significant decrease in NGAL in dialyzed patients after dialysis (4-6) months when compared to the same patients before starting dialysis $(\mathrm{p}<0.001)$ and there is statistically significant increase in NGAL in dialyzed patients before dialysis when compared to control group ( $\mathrm{p}=0.004)$, but there is no statistically difference in NGAL in dialyzed patients after dialysis when compared to control group ( $\mathrm{p}=0.16$ ).

A study analysis was performed on 139 outpatient, Asian-Japanese, maintenance HD subjects. HD patients compared to normal subjects as control to assess the diagnostic accuracy of serum NGAL level as a marker of malnutrition in maintenance hemodialysis patients (4). Another study performed (16) in which serum NGAL levels were evaluated as an inflammation marker on hemodialysis patients with permanent catheter. NGAL levels were markedly higher in $\mathrm{HD}$ patients than in healthy controls $(\mathrm{p}<0.05)(\mathbf{1 6})$.

Also a study was performed which was conducted with 61 chronic HD patients to prove that Neutrophil gelatinaseassociated lipocalin reflects the severity of anemia without iron deficiency and secondary hyperparathyroidism in hemodialysis patients they recorded serum NGAL levels were significantly higher in HD patients than controls $(\mathrm{p}=0.00)$ as
NGAL expression is stimulated by inflammatory cytokines such as interleukin (IL)-1 $\beta$ and IL-6, serum IL-1 $\beta$ levels are elevated in long-term HD patients and skeletal muscle synthesizes and secretes IL6 during HD session which may play a role in massively elevated serum NGAL levels in HD patients (14).

In the current study there is high statistically significant decrease in albumin in dialyzed patients after dialysis when compared to the same patients before dialysis $(\mathrm{p}<0.001)$ and there is high statistically significant decrease in albumin in dialyzed patients (before and after) dialysis when compared to control group ( $\mathrm{p}<0.001)$. This is in agreement with the result of other studies as they found that maintenance HD patients with reduced serum NGAL levels were prospectively associated with decrease in serum albumin levels, and had an increased likelihood to require admission for the treatment of infectious diseases. These findings could be caused by malnutrition and neutropenia, and by reduced NGAL's bacteriostatic activity $(4,17,18,19)$.

In the present study there is high statistically significant decrease in pre-albumin in dialyzed patients after dialysis when compared to the same patients before dialysis $(\mathrm{p}<0.001)$ and there is high statistically significant decrease in pre- 
albumin in dialyzed patients after dialysis when compared to control group $(\mathrm{p}<0.001)$. There were two studies agree with us as they showed statistically significant decrease in pre-albumin in dialyzed patients after dialysis when compared to the same patients before dialysis and high statistically significant decrease in pre-albumin in dialyzed patients after dialysis when compared to control group as pre-albumin is a sensitive marker for protein-energy malnutrition $(4,20)$.

In this study we observe high statistically significant decrease in serum iron and serum ferritin $(\mathrm{p}<0.001)$ in dialyzed patients after dialysis when compared to the same patients before dialysis. There is high statistically significant decrease in serum iron $(\mathrm{p}<$ 0.001) in dialyzed patients (before and after) dialysis when compared to control group. And there is a statistically significant decrease in serum ferritin $(\mathrm{p}<0.005)$ in dialyzed patients after dialysis when compared to control group. The same result was reported by several studies as they found that HD patients had lower serum iron and ferritin levels than healthy group. Since NGAL is an iron carrier protein and involved in the maintenance of iron equilibrium $(4,14,16,17,18,19)$. In this study there is high statistically significant increase in TIBC $(\mathrm{p}<0.001)$ in dialyzed patients after dialysis when compared to the same patients before dialysis. There is a high statistically significant increase in TIBC (p $<0.001$ ) in dialyzed patients (before and after) dialysis when compared to control group. The same result was reported by other studies as they found that TIBC in HD patients were higher than healthy controls as NGAL may therefore play a physiological role during increased iron utilization and mobilization from stores. NGAL might also be involved in the maintenance of the iron balance in HD patients $(4,18,19)$.

In the present study, HD patients showed a high significant increase in CRP as there was highly statistically significant increase in positivity in CRP in dialyzed patients after dialysis when compared to the same patients before dialysis $(\mathrm{p}<0.001)$ and there was highly statistically significant increase in positivity in CRP in dialyzed patients before dialysis $(\mathrm{p}<0.001)$ and after dialysis ( $\mathrm{p}<0.001)$ when compared to control group. There is statistically significant increase in CRP titer in dialyzed patients after dialysis when compared to the same patients before dialysis. There are studies supported that the measurement of serum CRP might help to distinguish the relative contributions of inflammation and malnutrition to the development of hypoalbuminemia $(\mathbf{1 4}, \mathbf{1 6}, \mathbf{1 8}, 19)$. They reported elevation of serum CRP in HD patients than healthy controls. In contrast to 
us there was a study recorded non statistically significant difference as regard CRP levels among studied groups (4).The reasons may include blood neutrophil (or WBC) counts were evaluated only in their study and contribution of CRP was incorporated into neutrophil counts, and their patients had much lower CRP levels (median $0.1 \mathrm{mg} / \mathrm{dl}$ ) compared to reports by Bolignano et al. (2010) (median $0.8 \mathrm{md} / \mathrm{dl}$ ) (18) and Malyzko et al. (2009) (mean 0.7 mg/dl) (19).

The current study observe highly statistically significant positive correlation between serum NGAL before dialysis and serum creatinine $(\mathrm{r}=0.732, \mathrm{p}<0.001)$, TLC $(\mathrm{r}=0.498, \mathrm{p}=0.005)$ and neutrophils $\%(\mathrm{r}=$ 0.424, $\mathrm{p}=0.02$ ) as shown in table (7). Similarly, there were studies agree with us $(4,14,16,17,18,19)$. According to our search, there were highly statistically significant positive correlation between serum NGAL after dialysis and albumin $(\mathrm{r}=$ 0.681, $\mathrm{P}=0.001$ ) as shown in table (8). Authors studied correlation of baseline serum NGAL levels with changes in serum albumin levels after a year serum albumin levels were stable in the highest and middle NGAL. In the lowest NGAL, serum albumin levels showed a significant decrease $(\mathrm{P}<0.05)$ (4). Conversely, NGAL levels were negatively correlated with serum albumin levels (r: -0.494, p: 0.000), as the albumin is negative acute phase reactant but they considered that was a limitation of their study may be due to it was executed in a single center and with relatively small groups (16).

In this study there was highly statistically significant positive correlation between serum NGAL after dialysis and serum iron $(\mathrm{r}=0.570, \mathrm{P}=0.001)$ and neutrophils $\%(\mathrm{r}=$ 0.643, $\mathrm{p}=0.001)$. And there were statistically significant positive correlation between serum NGAL after dialysis and prealbumin $(r=0.594, P=0.006)$, serum ferritin $(\mathrm{r}=0.396, \mathrm{P}=0.03)$ and TLC $(\mathrm{r}=$ $0.539, \mathrm{p}=0.008$ ) but and there was statistically significant negative correlation between serum NGAL after dialysis and TIBC ( $\mathrm{r}=-0.469, \mathrm{P}=0.009)$ as shown in table (8). Imamaki et al., (2015) agree with us and reported same results (4). We investigated development of severe infection after a period of HD by assessment of (CRP,TLC and Neutrophil \%), changes in serum albumin and pre-albumin levels as a representative indicator of nutritional status and evaluate indices of iron homeostasis ( $\mathrm{Hb} \%$, serum iron, serum ferritin and TIBC ) to detect anemia. All this parameters were done to detect malnutrition. We observed that in HD patients $(n=30)$ $83.3 \%$ of them suffered from malnutrition $(n=25)$ and $16.7 \%$ did not had malnutrition $(\mathrm{n}=5)$ as shown in table $(5)$ 
Our study observed that NGAL is a strong predictor of malnutrition in hemodialysis as there was statistically significant decrease in NGAL in before dialysis patients with malnutrition when compared to before dialysis patients without malnutrition $(\mathrm{P}=$ 0.21) and there was highly statistically significant decrease in NGAL after dialysis patients with malnutrition when compared to after dialysis patients without malnutrition $(\mathrm{P}=0.001)$ as shown in figure (1) and (2).

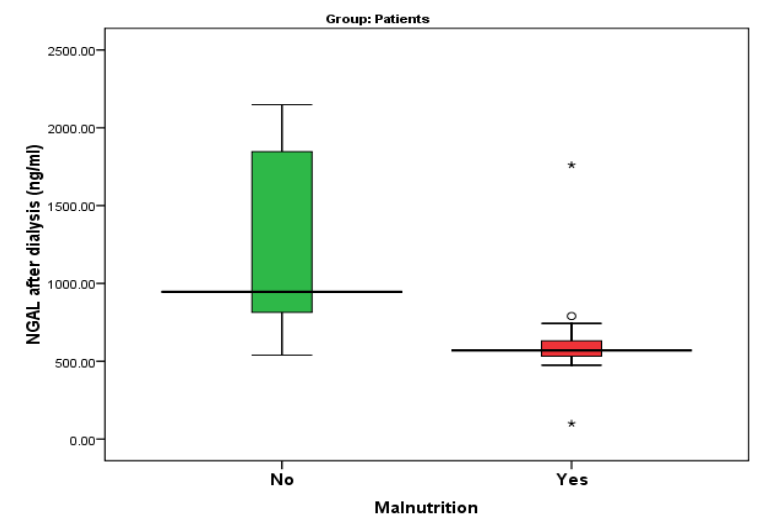

Figure (1) : Level of NGAL (ng/ml) after dialysis according to malnutrition.

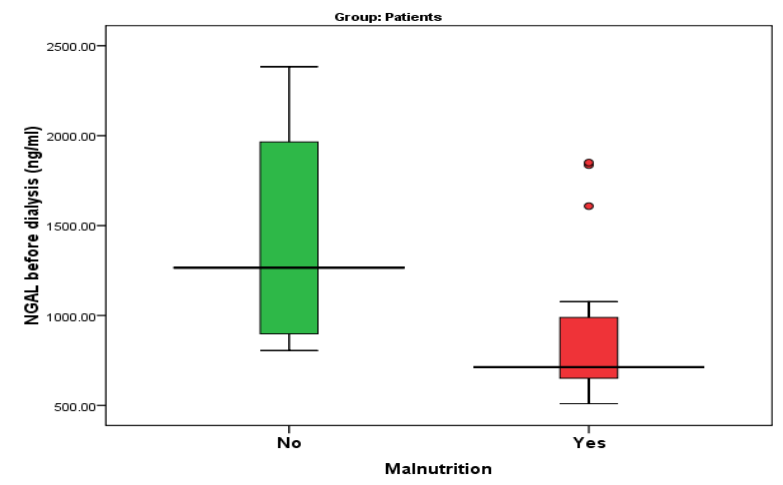

Figure (2) : Level of NGAL (ng/ml) before dialysis according to malnutrition.
In the current study, according to receiver operating characteristic curve (ROC), NGAL before HD area under the curve (AUC) was 0.848 ( 95\% CI, 0.64-1.0 ). The cut off value of NGAL before HD was $\leq 849$ ( $\mathbf{n g} / \mathbf{m l}$ ) with a sensitivity of $92 \%$, specificity $80 \%$, positive predictive value ( PPV ) $95.8 \%$ and negative predictive value ( NPV ) $66.7 \%$ with a diagnostic accuracy of $90 \%$ and NGAL after HD area under the curve (AUC) was 0.968 ( $95 \% \mathrm{CI}$, 0.9-1.0).

NGAL was reliable to predict malnutrition $\mathrm{P}$ $=0.001$. The cut off value of NGAL after HD was $\leq 600.5(\mathbf{n g} / \mathbf{m l})$ with a sensitivity of $100 \%$, specificity $80 \%$, positive predictive value ( PPV ) $96.1 \%$ and negative predictive value (NPV) $100 \%$ with a diagnostic accuracy of $96.7 \%$ as shown in figure (3).

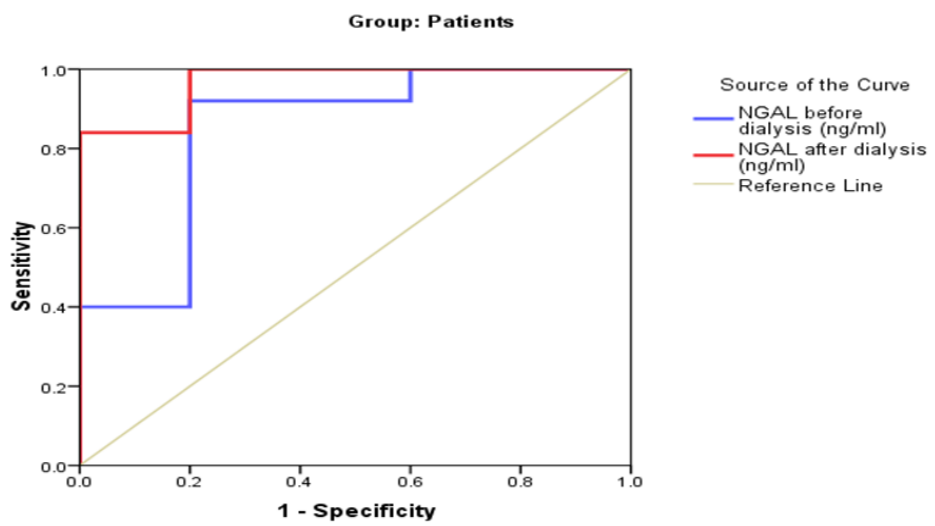

Figure (3): ROC curve for the performance of NGAL in prediction of malnutrition. 
This in agreement with Imamaki et al. ( 2015) where prediction of malnutrition in maintenance hemodialysis patients on the basis of serum NGAL was done using ROC curve and area under curve ( AUC ) was calculated. The sensitivity was $97.89 \%$, specificity was $93.55 \%$, positive predictive value (PPV) was $98.58 \%$, negative predictive value (NPV) was $90.63 \%$, area under curve (AUC) was 0.87 and accuracy index was $97.11 \%$ (4). Importantly, in this study the correlation of NGAL with albumin after dialysis $(\mathrm{r}=0.681, \mathrm{P}=0.001)$ was the strongest among markers studied in this study, suggesting that serum NGAL levels may be especially useful for the prediction of alteration in nutritional conditions among HD patients. These findings elucidated that HD patients with reduced serum NGAL levels may have increased risk to develop severe infection and large reduction in serum albumin concentrations. This in agreement with Imamaki et al. (2015) as they found a correlation of NGAL with albumin after dialysis $(\mathrm{r}=0.36, \mathrm{P}<0.01)$ and considered that an important correlation for the prediction of alteration in nutritional conditions among HD patients (4).

In current study we found that predictors of malnutrition were NGAL before HD was $\leq$ 849( $(\mathbf{n g} / \mathrm{ml}$ ), NGAL after HD was $\leq$ 600.5( $\mathrm{ng} / \mathrm{ml})$, albumin after HD $\leq \mathbf{3 . 8 5}$ ( $\mathbf{g} / \mathbf{d l}$ ), increase incidence of anemia (decrease in $\mathrm{Hb} \%$,serum iron and serum ferritin) and increase tendency of inflammation and infection ( increase in TLC and CRP titer) in after HD patients as shown in table (6).

\section{Conclusion}

this work indicated the importance of lipocalin-2 ( NGAL ) level as a marker of malnutrition in maintenance hemodialysis patients. So, serum NGAL levels might be a marker down regulated in HD patients and might be proposed as a new investigational tool for the prediction and management of malnutrition in maintenance hemodialysis patients.

\section{References}

1. Mahfouz MH, Assiri AM, Mukhtar MH. Assessment of Neutrophil Gelatinase-Associated Lipocalin (NGAL) and Retinol-Binding Protein 4 (RBP4) in Type 2 Diabetic Patients with Nephropathy. Biomarker Insights 2016;11:31-40.

2. Bao G, Clifton M, Hoette M, Mori K, Deng SX, Qiu A, et al. Iron traffics in circulation bound to a siderocalin (Ngal)-catechol complex. Nat Chem Biol 2010; 6(8): 602-609.

3. Liu KD, Yang W, Go AS, Yuan T, Zhang Y, Chen LQ,et al. Urine Neutrophil GelatinaseAssociated Lipocalin and Risk of Cardiovascular Disease and Death in CKD: Results From the Chronic Renal Insufficiency Cohort (CRIC) Study. Am J of Kidey Dis: the official journal of the National Kidney Foundation 2015; 65(2): 267-274. 
4. Imamaki H, Ishii A, Yokoi H, Koga K, Sugawara A, Yasuno $S$,et al. Low Serum Neutrophil Gelatinase-associated Lipocalin Level as a Marker of Malnutrition in Maintenance Hemodialysis Patients. PLoS One 2015 ; 10(7): e0132539.

5. Piechota-Polanczyk A, Demyanets S, Mittlboeck M, Domenig C, Neumayer C, Wojta J,et al. The Influence of Simvastatin on NGAL, Matrix Metalloproteinases and Their Tissue Inhibitors in Human Intraluminal Thrombus and Abdominal Aortic Aneurysm Tissue. Eur J Vasc Endovasc 2015 ; 49(5): 549-555.

6. Doumas BT, Watson WA, Biggs $H$. Albumin standard and the measurement of serum albumin with bromocresol green. Clin Chim Acta 1971; 31:87-96.

7. Yamanishi $\mathrm{H}$, Kimura S, Iyama S, Yamaguchi Y, Yanagihara T. Fully automated measurement of total iron-binding capacity in serum. Clin Chem 1997;43(12):2413-2417.

8. Dreux C. Selected method Analysis of human serum: assay of iron II. Method using bathophenanthroline Se-Iron II (bathophenanthroline) . ; Ann. Biol.Clin 1977; $35: 275$.

9. Anderson $\mathrm{H} \quad \mathrm{C}$ and McCarthy $\mathrm{M}$. Determination of C-reactive protein in the blood as a measure of the activity of the disease process in acute rheumatic fever. Am J Med 1950; $8(4): 445-455$.

10. Trinder P. Determination of glucose in blood using glucose oxidase with on alternative oxygen receptor. Ann Clin Biochem 1969; 6: 24 33.

11. Peake $\mathbf{M}$ and Whiting $\mathbf{M}$. Measurement of serum creatinine- current status and future goals. Clin Biochem 2006; 27: 173-184.
12. Furuya F, Shimura H, Yokomichi H, Kousios A, Kouis P, Panayiotou AG, et al. Neutrophil gelatinase-associated lipocalin levels associated with cardiovascular disease in chronic kidney disease patients. Clin and Exp Nephrol 2014;18(5): 778-783.

13. Paragas N, Qiu A, Zhang Q, Samstein B, Deng S-X, Schmidt-Ott KM, et al. The Ngal reporter mouse detects the response of the kidney to injury in real time. Nat Med 2011;17(2):216222 .

14. Yigit I, Ulu R, Gozel N, Taskapan H, Ilhan $\mathrm{N}$ and Dogukan A. Neutrophil gelatinaseassociated lipocalin reflects the severity of anemia without iron deficiency and secondary hyperparathyroidism in hemodialysis patients. Clin Istanb 2017; 4(1): 36-42.

15. Iannaccone $\mathrm{M}$ QG, Taha S, D'Ascenzo F, Moselewski F , Iftima N, Montefusco A, et al. Prevalence and predictors of culprit plaque rupture at OCT in patients with coronary artery disease: a meta-analysis. Eur Heart J Cardiovasc Imaging 2016; 17(10):1128-1137.

16. Yigit IP, Celiker H, Dogukan A, Ilhan N, Gurel A, Ulu R, Aygen B. Can serum NGAL levels be used as an inflammation marker on hemodialysis patients with permanent catheter? Ren Failure 2015 ; 37(1): 77-82.

17. Naudé PJ, Mommersteeg PM, Gouweleeuw L, Eisel UL, Denollet J, Westerhuis LW, Schoemaker RG. NGAL and other markers of inflammation as competitive or complementary markers for depressive symptom dimensions in heart failure. World. J Biol Psychiatry 2015; 16(7): 536-541.

18. Bolignano D, Coppolino G, Lacquaniti A, Buemi M. From kidney to cardiovascular diseases: NGAL as a biomarker beyond the 
confines of nephrology. Eur J Clin Invest 2010; 40 : 273-276.

19. Poniatowski B, Malyszko J, BachorzewskaGajewska H, Malyszko JS, Dobrzycki S. Serum neutrophil gelatinase-associated lipocalin as a marker of renal function in patients with chronic heart failure and coronary artery disease. Kidey \& Blood Pressure Research 2009; 32(2): 77-80.
20. Bacci M, Chehter E, Azzalis L, Alves $\mathrm{B},{ }^{1}$ and Fonseca F. Serum NGAL and Cystatin C Comparison With Urinary Albumin-to-Creatinine Ratio and Inflammatory Biomarkers as Early Predictors of Renal Dysfunction in Patients With Type 2. Diabetes Kidney International Reports 2017 ; 2(2): 152-158.

To cite this article: Anas Abd AlRahman, Hesham A. Esaa, Enas S. Ahmad, Seham S. Mohammed. Serum Neutrophil Gelatinase- Associated Lipocalin as a Marker of Malnutrition in Maintenance Hemodialyzed Patients. BMFJ 2021;38(1):169-184. DOI:10.21608/bmfi.2020.17522.1082 